\title{
LOS CALLEJONES DE LA ETNOFICCIÓN LADINA EN EL ÁREA MAYA (YUCATÁN, GUATEMALA, CHIAPAS)
}

Hace unos veinte años, J. Sommers ${ }^{1}$, ante la pujanza de una narrativa regional en el estado mexicano de Chiapas, señaló el fenómeno de una "nueva corriente literaria" cuyo interés radicaba, para él, en una nueva actitud de los intelectuales mexicanos hacia los grupos indígenas -en este caso mayances- y su cultura. El crítico norteamericano aludía a Ricardo Pozas (Juan Pérez Jolote, 1948), Ramón Rubín (El callado dolor de los tzotziles, 1949), Rosario Gastellanos (Balún Canán, 1957, etcétera), Eraclio Zepeda (Benzulul, 1959) y M. Lombardo de Caso (La culebra tapó el rio, 1962). Chiapanecos de origen o por elección, estos escritores revolucionaban, según Sommers, la tradicional escritura indigenista, gracias sobre todo a su mayor familiaridad con el mundo indígena, al abandono del didactismo social y a la apertura hacia una estética literaria más moderna. Si estas observaciones siguen siendo fundamentalmente válidas - aunque no para Rubín ni para Lombardo de Caso- , la creciente distancia temporal respecto a las obras reseñadas por Sommers permite ahora un nuevo examen dentro de un contexto ampliado. Agotado en pocos años, el ciclo narrativo de Chiapas, en efecto, no fue totalmente nuevo ni aislado. Lo precedió y acompañó un breve "ciclo" yucateco (A. Mediz Bolio, La tierra del faisán y del venado, 1922; E. Abreu Gómez, Canek, 1940, y La conjura de Xinum, 1958), como también la actividad literaria del guatemalteco M. A. Asturias (Leyendas de Guatemala, 1930; Hombres de maiz, 1949). Asturias, precisamente, escribió la novela más ambiciosa y compleja, no del "ciclo de Chiapas", sino de una serie literaria mayor, caracterizada por la tendencia

1 "El ciclo de Chiapas: nueva corriente literaria", CuA, 1964, núm. 2, 246-461. 
de sus autores, guatemaltecos o mexicanos, a incorporar elementos significantes de origen o apariencia mayance.

Resulta legítimo, desde luego, interrogarse acerca de la pertinencia de un criterio "étnico" para considerar un conjunto de prácticas literarias que se realizan, de hecho, en el seno de las sociedades ladinas respectivas, sociedades no "étnicas"' sino supuestamente nacionales o regionales. Sólo el examen crítico de los textos y su contextualización histórico-social permitirá decidir si el "área maya" corresponde a una realidad aislable desde el punto de vista de la producción literaria. Queremos adelantar, sin embargo, algunos argumentos que acreditan la legitimidad de tal delimitación. Todos los narradores implicados inscriben sus textos de algún modo en el campo de las tensiones entre sociedades ladinas y subsociedades mayances. De este modo, producen una narrativa de signo "regional", lo que significa algo distinto para los yucatecos o chiapanecos, por una parte, y para Asturias, por otra. Los primeros tienden a adoptar, en el contexto de la literatura mexicana, una actitud periférica, mientras que el segundo se esfuerza por crear una literatura nacional, en un país cuya población es mayoritariamente mayance. Ahora bien, todos coinciden, a diferencia de los demás escritores mesoamericanos, incluidos ciertos "indigenistas'” como F. Herrera y M. Monteforte Toledo (Guatemala) o R. Rubín (Chiapas), en la estrategia de inventar estructuras narrativas inéditas, por la adaptación o el traslado a la escritura de núcleos de (supuesto) discurso indígena, práctica que calificamos de "etnoficción". Como se verá, tal estrategia corresponde a la voluntad de superar, en la ficción, el antagonismo entre el sector ladino y las masas indígenas, obstáculo principal para la constitución, bajo dirección ladina, de sociedades regionales o nacionales homogéneas. La primera formulación de este proyecto estético común, la más ideológica también, se halla en una carta de Mediz Bolio incluida en el prólogo a La tierra del faisán y del venado:

...he pensado el libro en maya y lo he escrito en castellano. He hecho como un poeta indio que viviera en la actualidad y sintiera, a su manera peculiar, todas esas cosas suyas. Los temas están sacados de la tradición, de huellas de los antiguos libros, del alma misma de los indios, de sus danzas, de sus actuales supersticiones (restos vagos de las grandes religiones caídas) y, más que nada, de lo que yo mismo he visto, oído, sentido y podido penetrar en mi primera juventud, pasada en medio de esas cosas y de esos hombres. Todo ello me rodeó al nacer y fue impresionado, antes que por nada, por ese color, por esa melancolía del pasado muerto, que se hace sentir, 
sin sentir, en las ruinas de las ciudades y en la tristeza del hijo de las grandes razas desaparecidas...

La larga cita se justifica por la acumulación de tópicos ladinos acerca de los "hermanos" indios: "raza desaparecida", triste, supersticiosa, incapaz para actualizar la cultura de sus antepasados. Llama la atención, todavía, la pretensión ladina no sólo de conocer a los indios por haberse rozado con ellos, sino de tener el derecho de hablar en su nombre. Entre los escritores posteriores, dueños ya de una "conciencia antropológica", se seguirán manifestando tales deslices ideológicos, si bien bajo formas atenuadas: los ladinos como guías espirituales de las sociedades regionales.

Mediz Bolio, por otra parte, anuncia ya la mayoría de las técnicas que adoptarán los narradores ladinos para lograr un discurso literario de apariencia indígena: traslado de la sintaxis maya al español, construcción de una perspectiva indígena ficticia, referencia a las recopilaciones mayas coloniales, incorporación de creencias y prácticas rituales de los indios, recreación verbal de las antiguas formas arquitectónicas.

El ciclo narrativo del área maya es de hecho un interesante laboratorio de prácticas de "etnoficción", suscitadas por la peculiar inserción del intelectual ladino en una sociedad semicolonial. Dos de sus textos se convirtieron en "clásicos" de sendas corrientes literarias: Hombres de maíz, para el "realismo mágico" o "maravilloso"'s, y Juan Pérez Jolote, para el relato etno-testimonial. Los hombres verdaderos, por otra parte, es uno de los intentos de etnoficción más consecuentes que registra la literatura del subcontinente.

Nuestra exposición seguirá un criterio regional (YucatánGuatemala-Chiapas) que coincide, aproximadamente, con el orden de aparición de los textos. Iniciaremos cada apartado con una breve recapitulación de la historia de las relaciones interétnicas locales.

\section{YUCATÁN}

Pese a la debilidad política de los principados mayas del norte de la península, exhaustos por las guerras intestinas, pese también a las epidemias causadas ya, sin duda, por los virus euro-

\footnotetext{
2 ANTONIO MEDiz Bolio, La tierra del faisán y del venado, Contreras y Sanz, Buenos Aires, 1922.

${ }^{3}$ Cf. IRlemar ChIAMPI, El realismo maravilloso, Monte Ávila, Caracas, 1983.
} 
peos, la conquista española de Yucatán resultará, ante la encarnizada resistencia autóctona, particularmente difícil y sangrien$\mathrm{ta}^{4}$. Aún después de la derrota del estado maya independiente que los itzáes mantuvieron en el Petén hasta $1699^{5}$, una parte de la población maya seguirá sin integrarse a las nuevas estructuras socio-políticas. Proclamada la independencia mexicana, los ladinos se considerarán dueños de un territorio virtualmente autónomo, cuya economía se orientará, dada la falta de comunicaciones con México, hacia el Caribe, los Estados Unidos y Europa. La lucha por la supremacía política entre Campeche y Mérida se convertirá en antagonismo entre una orientación declaradamente independentista y un proyecto de autonomía en el seno de la federación mexicana. Movilizados, armados y manipulados por los dos bandos ladinos, los indios se verán empujados en 1847 a una guerra autodefensiva, conocida como "guerra de castas" 6 . En pocos meses, los mayas llegarán a controlar casi todo el territorio fuera de las capitales, pero los ladinos, ahora aliados, los obligarán a retirarse al oriente, donde el movimiento mesiánico de los cruzob, adoradores de la "cruz habladora", resistirá hasta comienzos del siglo $\mathrm{XX}^{7}$. El gobierno mexicano interviene dos veces para dividir la península: en 1858, Juárez autoriza la creación del estado de Campeche, y en 1902, Porfirio Díaz "regala" el territorio oriental recién pacificado (Quintana Roo) a un grupo de paniaguados. A partir de mediados del siglo XIX, los ladinos desarrollan una economía exportadora basada en el monocultivo del henequén, que transformará a vastos sectores de campesinos "milperos" en peones asalariados y oprimidos. La Revolución desencadena un profundo proceso de cambio: integración regional y nacional de Yucatán, modernización urbana, concentración de los campesinos en ejidos cooperativos, progresiva proletarización de los indígenas.

En este contexto de rápida transformación socio-cultural se inserta el libro principal de Mediz Bolio, intelectual de la aristocracia meridana y cofundador, en 1909, del Ateneo de la Juven-

${ }^{4}$ Cf. Silvanus G. Morley y George W. Brainerd, The Ancient Maya, rev. by R. J. Sharer, $4^{\text {a }}$ ed., University Press, Stanford, 1983.

${ }^{5}$ JUAN VillagutierRe SOTOMAYOR, Historia de la conquista de la provincia de Itzá, Soc. de Geografía e Historia, Guatemala, 1933.

6 SERAPIO BAQUEIRO, Ensayo histórico sobre las revoluciones de Yucatán (18711887), Club del Libro, Mérida (México), 1951-1952, 2 ts.

7 ROBERT REDField y Alfonso Villa Rojas, Chan Kom. A Maya Village, Carnegie Institution, Washington, 1934. 
tud, círculo de escritores y artistas mexicanos moderados que preparan el terreno cultural para el postporfirismo.

La tierra del faisán y del venado ostenta, sin embargo, no pocos rasgos que la vinculan con un género narrativo que dominó casi desde la Independencia, al lado de la historiografía, la vida literaria del Yucatán ladino: la "tradición"'. Consistía ésta, por lo común, en una elaboración romántico-nostálgica de escenas de la Conquista o de la vida colonial $^{9}$, como también en la recreación, al gusto ladino, de las tradiciones orales mayas ${ }^{10}$.

Al contrario de los libros de tradiciones, el texto de Mediz Bolio, compuesto por siete "libros", un "pórtico" y un "contrapórtico", revela un proyecto orgánico. La tierra del faisán y del venado - nombre que los mayas, según la crónica del franciscano Diego de Landa ${ }^{11}$, dieron a la península - evoca, al modo poemáticolegendario, un "Mayab" (Yucatán) intemporal. El narrador, autodesignándose baltzam (recitante) indio, no oculta su ambición de ofrecer una especie de equivalente moderno del Libro de Chilam Balam, recopilación maya colonial en que se mezclan discursos mítico-históricos, proféticos, rituales, calendáricos, etcétera. El propio Mediz Bolio, conocedor del maya, como gran parte de la aristocracia yucateca de la época, traduciría al español una de sus versiones, la de Chumayel ${ }^{12}$. Ahora bien, el contradictorio narrador de La tierra del faisán y del venado escribe en español y se refiere al "indio" como a una entidad ajena, expresando así, sin querer, la dificultad que experimenta el escritor ladino para convertirse en portavoz de indios y ladinos. Un examen detallado del texto revela, a cada paso, dicha ambigüedad. Varios libros presentan conocidas leyendas yucatecas sobre el pasado prehispánico del territorio. El "Libro de Chichén Itzá y de la princesa Sac-Nicté", por ejemplo, explica, basándose en el motivo del rapto de una esposa, la ruptura de la alianza entre las tres ciudades de la "liga de Mayapán": Uxmal, Chichén y la propia Mayapán, y el éxodo del clan dinástico itzá al Petén, hoy guatemalteco. Su fuente no es, como el texto sugiere, la tradición oral maya contemporánea, sino las

\footnotetext{
${ }^{8}$ A. MEDIZ Bollo, "Comentario inicial" en Gabriel ANTONIO MENÉNDEZ, Leyendas y tradiciones yucatecas, Club del Libro, Mérida (México), 1951, t. 2.

${ }^{9}$ Cf. El secreto del ajusticiado y otras leyendas yucatecas, t. 2, Ayuntamiento, Mérida (México), 1980.

${ }^{10}$ GABRIEL AntONIO MENÉNDEZ, op. cit.

${ }^{11}$ Relación de las cosas de Yucatán, ed. A. M. Garibay, $11^{\mathrm{a}}$ ed., Porrúa, México, 1978

${ }^{12}$ Libro de Chilam Balam de Chumayel, Lehmann, San José (Costa Rica), 1930.
} 
crónicas coloniales del yucateco López Cogolludo ${ }^{13}$ y del español Villagutierre ${ }^{14}$. El "Libro de Uxmal y del rey enano", por otra parte, relata la historia del hijo de una bruja - nacido de un huevo- que vence al rey a través de una serie de pruebas. Si bien este núcleo de motivos existía en la tradición maya de la época ${ }^{15}$, Mediz Bolio lo tomó de la versión muy "aculturada" del historiador y novelista Eligio Ancona ${ }^{16}$. El descubrimiento, en 1942, de los Cantares de Dzitbalché, manuscrito maya de danzas rituales ${ }^{17}$, confirma, para el "Libro de las siete danzas", cuán alejado se hallaba Mediz Bolio de las tradiciones mayas.

El "truco" que emplea el autor para sugerir el carácter "maya" de su discurso poético-narrativo es la creación de un lenguaje especial que actualiza en el texto ciertos mecanismos de significación del idioma maya. Así, los nombres comunes o propios y los topónimos mayas instalados en el texto no son simples signos exóticos, sino elementos que desencadenan o determinan ciertos aspectos de la narración. Maní, por ejemplo, voz que encabeza un capítulo, no designa sólo la ciudad homónima, sino que anticipa con su significado: 'todo pasó', el relato del derrumbe de la civilización maya yucateca. En la historia del príncipe Can-Ek: 'negraserpiente' y Sac-Nicté: 'blanca-flor', la etimología de los nombres propios determina los dos aspectos complementarios de los personajes, el humano (príncipe/princesa) y el natural (serpiente/flor). La verdadera flor sac-nicté, que florece en el mes maya de moan (20 de abril a 10 de mayo), es el factor mnemónico que suscita anualmente, según el texto, el recuerdo de la leyenda.

Una particularidad estilística, el uso frecuente de la construcción NOMBRE/PRONOMBRE + PROPOSICIÓN RELATIVA CON FUNCIÓN DE EPÍTETO ("la época en que se hacen nuevas todas las cosas", "Aquél a quien no se ve"), sugiere al lector el origen oral-sagrado del discurso narrativo, efecto reforzado por una poética basada en las repeticiones y los paralelismos rítmico-sintácticos. Si bien la construcción mencionada resulta realmente de la traducción de las composiciones nominales del

13 Historia de Yucatán (1688), Gobierno del Estado, Campeche (México), 19531955,3 ts.

14 Op. cit.

15 Cf. R. REDField y A. Villa Rojas, op. cit.

${ }^{16}$ Historia de Yucatán desde la época más remota hasta nuestros días, $2^{\mathrm{a}} \mathrm{ed}$., Imprenta de Jaime Jepùs Roviralta, Barcelona, 1889, 4 ts.

17 Alfredo BARRERA VÁSQUEZ, Libro de los cantares de Dzitbalché, Instituto Nacional de Antropología e Historia, México, 1965. 
maya ${ }^{18}$, su eficacia se debe sin duda a las asociaciones bíblicas que despierta en el lector.

¿Cuál es el referente histórico de La tierra del faisán y del venado? Cuatro de los siete libros reinterpretan, en términos semejantes a las evocaciones medievalizantes del modernismo (simbolismo), las épocas de esplendor y de decadencia de las ciudades mayas del norte de Yucatán. El derrumbe de la civilización maya no se atribuye, como espera el lector, a la irrupción de los españoles, sino a las disidencias internas. Los demás libros y los " pórticos", si bien enfocan al campesino maya contemporáneo, no diseñan en realidad ningún horizonte contemporáneo: se escamotea no sólo la situación neocolonial (señalada indirectamente por el idioma y la perspectiva narrativa), sino la misma existencia de los ladinos. El indio es el Indio por excelencia, ser ahistórico y asocial; su cultura, fuera de algunas creencias como la que se centra en la Xtabay (espíritu maligno con apariencia de mujer hermosa), se reduce a un animismo muy genérico. Como guionista de La noche de los mayas (1929), película de Chano Urueta, Mediz Bolio aplicará a la cultura maya una perspectiva reduccionista análoga ${ }^{19}$.

El referente verdadero de este libro dedicado a un Mayab no histórico, sino mítico-literario e ideológico, es la tradición ladina. Si Mediz Bolio la modifica, borrando la Conquista y la Colonia de la memoria literaria, es quizás para acercarse a los mayas míticohistóricos, no a sus contempóraneos. Al eliminar la Conquista, se elimina también la duda que pesa sobre la legitimidad del poder ladino, instaurado en última instancia por aquélla. En un Mayab intemporal, que no conoció el trauma de la Conquista, el ladino, libre ya de cualquier sospecha de culpa, puede atribuirse una borrosa ascendencia maya y hablar, quitándoles la palabra, en nombre de los indios antiguos y modernos.

En el extremo opuesto, aparentemente, se halla el Mayab creado por Abreu Gómez en Canek y en La conjura de Xinum: un territorio que vive al ritmo del antagonismo histórico entre ladinos y mayas. Apoyándose, como su colega, en fuentes ladinas, pero en las que enfocan los momentos de tensión social e interétnica, Abreu Gómez, identificado sin duda con los postulados indigenistas del sexenio cardenista (1934-1940), invierte, respecto

\footnotetext{
18 A. BARRERA VÁSQUEZ, "La lengua maya de Yucatán", en Enciclopedia Yucatanense, t. 6, Gobierno del Estado, Yucatán (México), 1977, pp. 205-292. ${ }^{19}$ Véase EMILIO GARCÍA RIERA, Historia documental del cine mexicano, Era, México, 1969, t. 1.
} 
a sus fuentes, los papeles de "buenos" y "malos".

Canek $^{20}$ actualiza, trasladando los sucesos a un presente algo ucrónico, la que los historiadores ladinos califican de "insurrección maya de Quisteil"' (1761). Este movimiento, que no pasó en realidad de una respuesta local a los abusos de un latifundista, fue interpretado por la tradición ladina como la expresión de una peligrosa actitud anti-ladina generalizada ${ }^{21}$. Así lo presenta, poco antes del estallido de la "guerra de castas", el trasfondo seudohistórico de un romántico relato de amor interétnico, "La hija del sublevado" (1845) de Rafael Carvajal22. Abreu Gómez, aceptando hasta cierto punto tal interpretación, justifica la actitud de los rebeldes.

La novela se compone de una rápida sucesión de secuencias breves que presenta, a modo de parábolas, las características y la evolución de las relaciones interétnicas. En la mayoría de los casos, la última palabra pertenece a Jacinto Canek, indio formado, según la tradición ladina, en teología moral ${ }^{23}$. La ausencia textual del terrateniente, al comienzo, permite relaciones excelentes entre los indios y los miembros "secundarios" (niños y mujeres) de la familia ladina. Se constata, incluso, una notable "aculturación a la inversa"' de esta última: la adopción, por ejemplo, del ritual indígena ante un eclipse de luna (II, 32). La intransigencia latifundista transformará, poco a poco, la situación. Canek inculcará a sus compañeros una doctrina moral totalmente anti-ladina. La guerra, inevitable al fin, culmina con la matanza de los indios y la ejecución del dirigente. Los indios sobrevivientes, "mesiánicos", no aceptan la realidad de la muerte de Canek. Las relaciones amistosas que se habían tejido entre el indio sabio y el niño Guy, sobrino sensible del terrateniente, y el camino común que emprenden, ya muertos, los dos protagonistas al final de la novela, sugiere la utopía de un mundo "mestizo" sin tensiones interétnicas ni sociales.

Los epígrafes de los diferentes capítulos, extraídos en su casi totalidad del Libro de Chilam Balam, especialmente de las famosas profecías de los Ah Kines, indican la voluntad del autor de inscribir su libro, dentro de la ficción, en la tradición indígena. Refuerza esta impresión de ficticia continuidad la aparición, en tanto que

${ }^{20}$ E. Abreu Gómez, Canek, $42^{\mathrm{a}}$ ed., Oasis, México, 1980.

${ }^{21}$ VICENTE CASARRUBIAS, Rebeliones indígenas en la Nueva España, Ministerio de Educación Pública, Guatemala, 1951.

22 Publicado en El secreto del ajusticiado y otras leyendas yucatecas, Ayuntamiento, Mérida (México), 1980.

${ }^{23} \mathrm{Cf}$. Vicente CASARRUBIAS, op. cit. 
personaje secundario, del nieto de Juan José Hoil, compilador maya del Chilam Balam de Chumayel.

Comparando Canek con La tierra del faisán y del venado se comprueba que ha cambiado la actitud política del escritor, pero no los medios de la etnoficción ladina. Al igual que la obra de Mediz Bolio, Canek resulta en buena medida una mistificación - "bien intencionada" - del discurso indígena. La introducción del niño ladino Guy, personaje que realiza en el texto una especie de alter ego del autor, permite matizar un poco este juicio: su proximidad con respecto a Abreu Gómez neutraliza, hasta cierto punto, las ficticias condiciones "indígenas" de la producción del texto.

La conjura de Xinum ${ }^{24}$, crónica novelesca de la guerra de castas, no entra realmente en el terreno de la etnoficción. El narrador, ubicuo, "vuela" de un campo a otro y observa a partir de su perspectiva, pero sin asentarse en las conciencias de los protagonistas. Como las crónicas españolas de la Conquista, ubicadas en la frontera entre la historiografía y la ficción, La conjura admite, sobre todo cuando el narrador se halla en el campo indígena, la aparición de sucesos maravillosos; el texto no los refiere, sin embargo, a ningún discurso indígena. Este relato, independientemente de su interés literario, nos concierne aquí sobre todo por su relación temática con Oficio de tinieblas de Rosario Castellanos (evocación de las "guerras de castas" de la segunda mitad del siglo XIX en Yucatán y Chiapas), y por las declaraciones que el texto inspiró a su prologuista, M. A. Asturias.

Adoptando un plural más que equívoco ("nosotros indígenas de nacimiento, pensamiento o vocación"), Asturias reivindica la ascendencia indígena de La conjura. "Nuestra historia - diceno está toda escrita, pero está hablada". Los escritores - Abreu Gómez y el propio Asturias- la escriben y convierten en texto "sagrado"; ellos trabajan "en reclamo de los que por nuestro verbo hablan, piden, claman, lloran, se arrebatan, protestan, ríen con risa de máscaras o se conforman con callar". La obra - "sueño real" - no se refiere a ninguna época, porque todas las épocas desde la Conquista se asemejan. Las floridas declaracionesdeclamaciones del escritor guatemalteco, poco adecuadas a la crónica de Abreu Gómez, son significativas en la medida en que aluden a su propia práctica literaria; en definitiva, repiten el programa anunciado casi treinta años antes por Mediz Bolio.

${ }^{24}$ E. ABreu GómeZ, La conjura de Xinum, pról. M. A. Asturias, Ministerio de Cultura, San Salvador, 1958. 


\section{GUATEMALA}

Al mando del general Tecum Umán, las tropas del reino quiché resisten algún tiempo a la arremetida de los españoles y sus aliados mexicanos y cakchiqueles. Con la insurrección fallida de los últimos, ya arrepentidos, el territorio centroamericano queda, fuera de los reductos selváticos de itzáes y lacandones, "pacificado" bajo el nombre de Capitanía General de Guatemala. Los clásicos mecanismos de autogobierno indígena local suscitan una nueva aristocracia guatemalteco-mexicana, en general adicta al poder colonial, pero auspician también la preservación de los reflejos "étnicos". Una serie de levantamientos locales contra el tributo real ${ }^{25}$ preceden, sin prepararla, una independencia criolla en el marco del imperio mexicano de Iturbide. El proyecto de unas Provincias Unidas de América Central toma forma, pero no sobrevive a las maniobras de división orquestadas por las potencias imperialistas y por México. Chiapas pasará a México, Belice será ocupado por los ingleses y, poco a poco, se irán constituyendo las entidades políticas actuales. La República, que reitera primero la política colonial de protección a los indios, agrava después, sobre todo con la reforma liberal de Rufino Barrios (1871), la situación de las subsociedades "étnicas": de "protegidos", los indios pasarán a "ciudadanos de segunda clase". Amenazados, reaccionan con varias sublevaciones siempre circunscritas a un grupo étnico y a uno o pocos municipios ${ }^{26}$. La creciente penetración imperialista, especialmente norteamericana, esclaviza a una parte de los indios (plantaciones de la United Fruit) y desestabiliza profundamente un país poco integrado. En Guatemala, contrariamente al Yucatán moderno y a Chiapas, estados (periféricos) de México, el llamado "problema indígena" -en realidad, el de la creación de un sistema democrático- es el problema nacional central ${ }^{27}$. Contra el peligro de una desintegración fatal por factores tanto internos (poder semicolonial) como externos (imperialismo), la revolución de 1944 intenta a la vez democratizar y "nacionalizar" el país, proyecto destruido, ya después de la publicación de

${ }^{25} \mathrm{~J}$. DANIEL CONTRERAS, Una rebelión indígena en el partido de Totonicapan en 1820, Edit. Universitaria, Guatemala, 1968.

${ }^{26}$ Para más datos sobre las sublevaciones véanse J. D. CONTRERAS, op. cit. y ADRIÁN RECINOS, Monografía del departamento de Huehuetenango, $2^{\text {a }}$ ed. corr., Ministerio de Educación Pública, Guatemala, 1954.

27 CARLOS GUZMÁN BOCKLER y JEAN-LOUP HERBERT, Guatemala: una interpretación histórico-social, Siglo XXI, México, 1970. 
Hombres de maíz de Asturias, por el conocido golpe derechista de 1954 apoyado por los norteamericanos.

La interpretación de Hombres de maíz ${ }^{28}$ - como tampoco la de cualquier otro de los textos aquí considerados - no puede circunscribirse a examinar el modo en que el escritor convierte en lenguaje artístico el conflicto histórico entre indios y ladinos en el área maya. Sin embargo, dedicamos aquí nuestra atención a este aspecto, punto de arranque para muchos malentendidos interpretativos. El éxito público de las tan frecuentes como contradictorias declaraciones de Asturias acerca de su "ascendencia maya" (mitología personal del premio Nobel) justificaría por sí solo este enfoque.

En la medida en que la novela parte de la histórica - aunque mitificada en el texto- lucha de los indios ixiles de Ilóm contra el cultivo capitalista de la planta sagrada del maíz ${ }^{29}$, Hombres de mai $z$ arrastra un "pasado" indigenista. El comienzo del texto, por otra parte, contado por un narrador interior al universo indígena de la ficción, presenta notables rasgos de "etnoficción". El conjunto de la novela desmentirá, parcialmente, estas dos líneas iniciales. Mediante una estética sui generis, la narración evoca cuatro etapas o generaciones de una humanidad de ficción; cuatro situaciones histórico-espaciales que se asemejan a los cuatro modelos de la relación indios/ladinos que coexisten en el continuum aculturativo que Redfield ${ }^{30}$ formalizó para Yucatán. Al repartir las cuatro "humanidades" (parodia del Popol Vuh) a la vez en el tiempo y en el espacio, Asturias, como lo había hecho Eisenstein en su película ¡Que viva México! (1931-1932), acaba por superponerlas. Esta sola operación bastaría para alejarlo de los indigenistas "didácticos", testigos, en la ficción, de la opresión de los indios contemporáneos, aunque no de "neo-indigenistas" como Rosario Castellanos, para quien la superposición de varias coyunturas históricas es un instrumento de indagación privilegiado. Ahora bien, el referente indígena de Hombres de maíz carece, en realidad, de cualquier caracterización étnica, histórica o social precisa. Asturias no enfoca a unos grupos indígenas específicos (su atribución de una "nacionalidad" chuj a Nicho parece casual), ni tampoco al conjunto de los indios guatemaltecos. Sus universos indígenas

${ }^{28}$ M. A. ASTURIAS, Hombres de maiz, ed. Gerald Martin, Klincksieck, Paris; F.C.E., México, 1981.

${ }^{29}$ Véanse los comentarios críticos de G. Martin a la edición de Hombres de maiz arriba citada.

${ }^{30}$ The Folk Culture of Yucatan, University of Chicago Press, Chicago, 1941. 
o populares, si bien integran ciertas características socio-políticas, son más arquetípicos que históricos. La comunidad de Gaspar Ilóm, especialmente, no es una comunidad indígena construida con los recursos de la antropología o la etnohistoria (como lo será la que aparece en Los hombres verdaderos de Carlo Antonio Castro), sino una colectividad mítico-literaria. El objetivo prioritario de Asturias no es, sin duda, el de documentar la opresión que sufren los indios, ni el de rescatar, por medio de la etnoficción, sus valores específicos.

¿Qué papel desempeña, entonces, lo "maya" en Hombres de maiz? Asturias, como su colega, contemporáneo y compatriota Luis Cardoza y Aragón ${ }^{31}$, conoció la cultura maya en Europa; más aún, conoció Guatemala en el extranjero. Su tesis sobre el problema indígena (1923), realizada antes de emprender viaje, lo demuestra con su positivismo civilizador. En París, el futuro novelista conoció, no por casualidad paralelamente, el surrealismo y la cultura maya clásica, la de los museos y las bibliotecas. El surrealismo lo preparó para leer creativamente, no con ojos de etnohistoriador ni de antropólogo, el Popol-Vuh y otros textos semejantes ${ }^{33}$. Hombres de maiz, después de Leyendas de Guatemala, es un resultado mayor de esta lectura. Si se juzga no tanto según las declaraciones del autor, sino a partir del texto literario, Asturias quedó deslumbrado por la riqueza verbal e imaginativa del Popol$V u h$, riqueza que se apropió y transformó para crear un país de ficción cuyas coordenadas semióticas (elaboraciones sociolectales, núcleos de creencias mesoamericanas, palabras-signo mayas, guatemaltequismos) lo designan como "Guatemala". Contrariamente a las narraciones chiapanecas contemporáneas, testimonios de conflictos históricos regionales, la novela de Asturias edifica, a partir de elementos "artificiales", un mito literario capaz de definir la futura identidad cultural del país: la estrategia de Mediz Bolio, pero llevada al terreno de una refinada dialéctica literaria. La ausencia de preocupaciones de "verosimilitud" permite a Asturias mezclar o modificar creencias y prácticas indígenas de procedencia diversa. $\mathrm{Si}$, para los indios mayances, el nahual es un doble animal o espíritu protector de los individuos ${ }^{34}$, el de Sahagún

31 Guatemala: las líneas de su mano, $3^{\mathrm{a}}$ ed., F.C.E., México, 1976.

32 M. A. ASTURIAS, El problema social del indio, Institut d'Études Hispaniques, Paris, 1971.

33 CARLOS RINCÓN, "Nociones surrealistas, concepción del lenguaje y función ideológico-literaria del realismo mágico en M. A. Asturias", Escritura, Caracas, 5/6 (1978), 25-61.

${ }^{34}$ Como aparece documentado en RICARDO POZAS, Chamula, Instituto Nacio- 
(azteca o "transculturado") resulta un brujo capaz de convertirse en animal. El largo episodio de Asturias sobre el correo-coyote Nicho combina sugestivamente las dos opciones para terminar en un jungiano descenso a una cueva, metáfora del inconsciente colectivo. La curación de la ceguera de Goyo Yic, por otra parte, actualiza una práctica descrita en el mismo manuscrito de Sahagún ${ }^{35}$.

La prosodia, las imágenes y los conceptos inspirados en los del Popol Vuh y otras "crónicas" mesoamericanas, contribuyen a crear esa "magia" de apariencia maya ${ }^{36}$ que disimula la ausencia de los "indios verdaderos". La apropiación literaria de la cultura maya clásica en Hombres de maiz ofrece a primera vista una cierta analogía con la apropiación ladina, en el mundo real, de la figura histórica de Tecum Umán: las dos tienden a enmascarar la situación real. A este aspecto de mistificación se opone, en la novela de Asturias, una reflexión ficcionalizada sobre las transformaciones sucesivas de la materia mítica. A un "mito primitivo" pertenece la muerte, a raíz de una traición, del cacique de Ilóm, la maldición de los brujos de las luciérnagas contra los culpables y su cumplimiento: la inmolación en el fuego de Machojón hijo y de las tropas represivas. El episodio "mítico"' de Machojón hijo se convierte luego en chisme aldeano, antes de ser actualizado, como falsa realidad, por Machojón padre. Una leyenda inventada ante los ojos del lector por el personaje Hilario ("Miguelita de Acatán") se transforma en realidad colectiva. "Hilando" la historia de todos los sucesos y cuentos pasados, el mismo Hilario aparece en el texto como un doble interno del narrador, encargado de desmitificar la percepción mítica de la realidad novelesca. El personaje de un cura cronista que apunta y analiza otros sucesos mítico-novelescos contribuye a despertar el juicio crítico del lector. A través de éstas y otras manipulaciones, la novela cuestiona su propio status y se designa como ficción de ficciones. Considerada bajo esta perspectiva, la índole a primera vista demagógica de Hombres de maíz (una etnoficción sin base científica) resulta un juego dialéctico de mitificaciones, desmitificaciones y remitificaciones, capaz de suscitar en el lector una reflexión liberadora acerca de las contradicciones de la ficción ladina en el área maya.

nal Indigenista, México, 1959, 2 ts. y en CHARLes WAGLeY, Santiago Chimaltenango, Seminario de Integración Social Guatemalteca, Guatemala, 1957.

${ }^{35}$ Como lo señala G. Martin (ed.) en M. A. Asturias, Hombres de maiz.

${ }^{36}$ Ricardo EstradA, "Estilo y magia del Popol Vuh en Hombres de maiz de M. A. Asturias", Humanidades, Guatemala, 3 (1961), 1-16. 


\section{CHIAPAS}

El territorio del actual estado mexicano de Chiapas, vinculado desde tiempos remotos con el destino de los Altos de Guatemala, sometido a la Audiencia de Guatemala durante la Colonia, entra en la época posthispánica como parte del imperio de Iturbide, y pertenece durante un breve lapso a las Provincias Unidas de América Central antes de incorporarse, definitivamente, a la República Mexicana. El régimen de la hacienda, cuyo centro político es San Cristóbal, lo mantiene en un aislamiento propicio a la sobreexplotación y opresión de los indígenas, fundamentalmente mayas de idioma tzeltal y tzotzil. Desde el comienzo, periódicas sublevaciones indígenas sacuden la zona, en época "reciente" la de los tzeltales en 1712 y la "guerra de castas" (1868-1870) de los tzotziles. A partir del porfirismo, y contra los intereses de los latifundistas de los Altos, el centro político se traslada a Tuxtla, capital de las plantaciones de monocultivo (café, cacao, algodón) de la tierra caliente. La Revolución provoca una reacción de los hacendados antiguos, que vuelven a controlar la zona hasta $1935^{37}$. El sexenio cardenista favorece la constitución de ejidos cooperativos y el desarrollo de las fincas capitalistas en las tierras bajas. La política indigenista, cuyo órgano oficial será, más tarde, el Instituto Nacional Indigenista, tiende a acelerar la integración nacional por la escolarización de los indios, el desarrollo de las comunicaciones, la ladinización de los centros del interior.

El centro coordinador del Instituto Nacional Indigenista en San Cristóbal, el más antiguo de México, empieza a funcionar en 1951. Ocurre que los cuatro escritores significativos del "ciclo de Chiapas" trabajaron todos en algún momento para esa institución. Todos ellos, pues, independientemente de las circunstancias de su origen, tuvieron la oportunidad de observar desde bastante cerca la vida de los campesinos indígenas, la evolución de la relación indios/ladinos y la transformación rápida de la sociedad regional.

Un año antes de la aparición de Hombres de maiz (1949), el antropólogo mexicano Ricardo Pozas publica su "Biografía de un tzotzil', Juan Pérez Jolote. En 1959, Pozas entrega a la imprenta su estudio etnográfico sobre los tzotziles-chamulas, Chamula. El mismo año, precedido por Rosario Castellanos con su Balún Canán (1957), otro antropólogo, Carlo Antonio Castro, da a conocer su novela Los hombres verdaderos. También en 1959 aparece Benzulul de Era-

37 Christian DeverRe, Indiens ou paysans, Sycomore, Paris, 1980. 
clio Zepeda, seguido tres años más tarde por la segunda novela de Rosario Castellanos, Oficio de tinieblas.

El conjunto de estas obras abarca todo un espectro discursivo, desde la novela "pura" (Balún Canán) hasta el discurso etnográfico puro (Chamula), pasando, ante todo, por el discurso etnotestimonial de Juan Pérez Jolote y el "etnoficcional" por excelencia de Los hombres verdaderos. Los dos últimos textos, a primera vista homólogos de no ser por la diferencia que sugieren sus subtítulos (biografía/novela), introducen una decisiva novedad en la narrativa "etnoficcional" del área maya: un discurso "indígena" de apariencia auténtica puesto en boca de sendos narradores autobiográficos. La confrontación de las dos narraciones permite discutir el status de la demarcación que separa, en este caso, el discurso testimonial del discurso propiamente de etnoficción.

Los dos textos presentan la autobiografía de un individuo maya, de idioma tzeltal en Los hombres verdaderos ${ }^{38}$, y tzotzil en Juan Pérez Jolote ${ }^{39}$. Los dos discursos combinan la evocación de las peripecias individuales del protagonista con una descripción etnográfica apenas narrativizada de los ritos de pasaje (nacimiento, matrimonio, muerte...) y del ciclo anual, que ritman la vida de la colectividad. Algo paradójicamente, el discurso testimonial de Juan Pérez Jolote ofrece mayores desarrollos "novelescos" que el discurso ficcional de Los hombres verdaderos, que se ciñe a lo "verosímil". La realidad, se suele decir, supera siempre a la ficción, pero: ¿qué es en el fondo lo "real" y lo "ficticio" en estos textos? ¿En qué consiste realmente la diferencia entre el discurso testimonial y el discurso etnoficcional? Según el sentido común, el primero no hace sino reproducir por escrito un discurso oral que fue realmente pronunciado, mientras que el segundo imita - para no decir inventa - un discurso oral ficticio. La intervención creadora que acompaña, en los dos casos, el traslado del discurso indígena a la escritura, no permite aceptar esta primera respuesta: los dos discursos narrativos representan, en alguna medida, un trabajo de recreación escrita del discurso oral. La narrativa testimonial, no sólo por la necesidad de presentar un texto orgánico, sino también por las características de su producción (la encuesta dirigida), no garantiza de hecho una mayor fidelidad al discurso indígena en sí.

38 CARlo ANTONio CASTRO, Los hombres verdaderos, Universidad Veracruzana, Xalapa (México), 1959.

${ }^{39}$ Apareció originalmente en Acta Antropológica, México, 1948, núm. 3, 263-371. 
Se impone, pues, la introducción de otro criterio diferenciador, el del contrato que las particularidades del texto establecen entre el autor, el propio texto y el lector. Este contrato fija las reglas de la comunicación literaria prevista. Grosso modo, el contrato testimonial supone una relación existencial entre el discurso transcrito y el que fue pronunciado. No garantiza, en cambio, la veracidad del discurso "original" del informante ni su representatividad social, y admite, además, la libre selección y organización de los fragmentos discursivos reales. Más concretamente, el contrato válido para Juan Pérez Jolote no estipula que un indio tzotzil cualquiera haya pronunciado alguna vez su autobiografía tal como figura en el libro, sino tan sólo que los materiales presentados fueron proporcionados por él.

El contrato etnoficcional, por otro lado, no admite en ningún caso que el autor invente libremente todos los elementos de la narración; al leer una obra de etnografía ficcionalizada, el lector exige la verosimilitud de los aspectos propiamente "etnográficos" -la descripción de las prácticas sociales del grupo "étnico" elegido. En cambio, el lector supone que "los personajes y sucesos de la ficción no guardan ninguna relación con personas y sucesos reales", como reza el modo de empleo de muchas obras de ficción (por ejemplo, el cine).

A partir de toda la riqueza de su conocimiento antropológico, especialmente lingüístico-literario, Carlo Antonio Castro elaboró un discurso indígena verosímil en el contexto aludido, moldeado en unas imágenes y una sintaxis que trasladan al texto en español las particularidades de una percepción supuestamente tzeltal. La novela reproduce una serie de discursos codificados (narraciones mítico-legendarias), cuya autenticidad se puede comprobar al parangonarlos con los textos recopilados y publicados en versión bilingüe por el propio autor ${ }^{40}$. La lectura de la novela da la impresión de vivir, instalado en la conciencia de un individuo fuertemente identificado con su colectividad, la transformación actual de la sociedad regional.

El efecto de la lectura de Juan Pérez Jolote es muy distinto: el lector cree escuchar a un hombre maduro que cuenta, con un cierto desenfado, las peripecias "heroicas" de su vida pasada. Contrariamente al discurso autobiográfico en Castro, éste no alude de ningún modo a un supuesto "original" en idioma indígena, ante cuya traducción se encontrara el lector. Éste no se halla ficticia-

40 Carlo antonio Castro, Narraciones tzeltales de Chiapas, Universidad Veracruzana, Xalapa, 1965. 
mente instalado en una conciencia indígena, sino frente a un narrador, cuyos cuentos escucha con la actitud medio distante que se adopta en estos casos.

Ante la definitiva imposibilidad de presentar a un lector hispánico el discurso-pensamiento auténtico de un indio, las dos autobiografías ofrecen, pues, dos variantes sugestivas, igualmente válidas como criticables.

Después de la etnoficción ideologizante y demagógica de Mediz Bolio, después de Canek de Abreu Gómez, los procedimientos narrativos desarrollados por Pozas y Castro incorporan el avance decisivo de la reflexión antropológica. Contrariamente a lo que se desprende de Hombres de maíz, su problematización de la incómoda situación del escritor ladino frente al mundo indígena no pasa por la búsqueda de una mayor polisemia, sino por el conocimiento del "discurso del otro". En las novelas de Rosario Castellanos, las dos orientaciones se despliegan paralelamente.

Balún Canán ${ }^{41}$ narra, ubicando los acontecimientos en la época de la reforma agraria cardenista, el acelerado fin de una familia terrateniente que enfrenta un gobierno pro-campesino, el despertar y el levantamiento de sus peones tzeltales, la maldición de los brujos indígenas, circunstancias todas que se traducen en su autodisolución. La primera y la tercera partes de la novela se cuentan a partir de la perspectiva de una niña ladina, hija de los terratenientes; las condiciones ficticias de la producción del discurso novelesco se aproximan, por lo tanto, a las reales: una autora ladina que escribe sobre el mundo ladino e indígena. La regla sufre, sin embargo, una serie de derogaciones o inconsecuencias. Por una parte, la niña-testigo es capaz de reproducir, sin teñirlos con su visión infantil, discursos de adultos ladinos o indios, como también cartas y otros documentos escritos. En el cap. I, la narradora lee un cuaderno que se supone escrito por el "hermano mayor de la tribu" de Chactajal para los miembros de su comunidad. Inverosímil en español y para el siglo XX, este texto actualiza las resonancias de los textos mayas antiguos y la forma de los "títulos" genealógico-históricos, escritos que las élites indígenas coloniales presentaban ante las autoridades españolas para justificar sus reivindicaciones. Para convocar la presencia indígena, Rosario Castellanos se remite, pues, "a los textos mayances coloniales': a su traducción. Muy ilustrativo, en el mismo sentido, es el propio comienzo de la novela: el discurso de la nana tzeltal, que abre realmente la novela, aparece prácticamente como la con-

${ }^{41}$ Rosario Castellanos, Balún Canán, F.C.E., México, 1957. 
tinuación del epígrafe, cita de un camucú (canto de despedida) del Popol Vuh. El supuesto discurso tzeltal moderno se moldea en las imágenes del viejo discurso quiché. Con sus narraciones, por otra parte, la nana educa a la niña narradora de la novela; el lector percibe entonces una ficticia genealogía de discursos que empieza con el Popol Vuh para desembocar en la novela que lleva, no por casualidad, un título indígena: Balún Canán - los "siete guardianes", nombre de una constelación y antiguo nombre de la ciudad de Comitán. Para perfeccionar la ilusión, no sólo la primera parte de la novela sino cada una de ellas se abriga detrás de un epígrafe maya tomado del Popol Vuh, del Libro de Chilam Balam o de los Anales de los Xahil: demostración, una vez más, del callejón sin salida de la etnoficción ladina.

Más compleja es la situación en la segunda parte, la que cuenta los momentos más dramáticos del enfrentamiento entre indios y ladinos: el discurso oscila, por una parte, entre una visión omnisciente ladina y otra indígena; por la otra, la perspectiva se acerca a toda una serie de personajes ladinos e indios, cuyo discurso aparecerá bajo forma de diálogo, monólogo interior o exterior libre $\mathrm{y}$, otra vez, como memoria indígena escrita.

Oficio de tinieblas ${ }^{42}$ resulta, en más de un sentido, una ampliación de la segunda parte de Balún Canán. La novela más ambiciosa de Rosario Castellanos podría parecer, a primera vista, una repetición de La conjura de Xinum referida a la "guerra de castas" de Chiapas (1868-1870). Pero tanto el tratamiento de la historia como las articulaciones internas revelan un proyecto distinto. La posibilidad de un discurso en forma de crónica (informativo) se desvanece desde el comienzo al superponerse la insurrección "mesiánica" de los tzotziles al relato del proceso de reforma agraria cardenista. No es una novela histórica, como La conjura, sino una historia-ficción: reflexión, por medio de la ficción, sobre la propia historia y sobre su percepción por los actores históricos y sus descendientes. La historia no se cuestiona sólo a través de la superposición de varias coyunturas (tres, cuando se incluye la de la escritura ${ }^{43}$, sino también por la posición o simple yuxtaposición de versiones distintas: una práctica que recuerda, sin el aspecto de la "mitificación", la de Asturias en Hombres de maiz. De este modo la autora, anticipándose de algún modo a investigaciones más recientes ${ }^{44}$, cuestiona y destruye el tendencioso texto histo-

${ }^{42}$ Joaquín Mortiz, México, 1962.

43 JOSEPH SOMMERS, "Forma e ideología en Oficio de tinieblas de R. Castellanos", $R C L L, 1978$, núms. 7/8, 73-91.

${ }^{44}$ JAN RUS, "Whose Caste War? Indians, Ladinos and the Chiapas "Caste 
riográfico que le sirve de fuente: la Historia de las sublevaciones indigenas en el estado de Chiapas ${ }^{45}$. Su polilogía narrativa, no necesariamente convincente en sus aspectos de etnoficción, revela la índole monológica de la versión ladina tradicional.

La técnica de ubicuidad narrativa empleada ya, por motivos semejantes, en La conjura de Xinum, experimenta en esta novela de Rosario Castellanos una notable profundización: la perspectiva narrativa no se limita a instalarse en los dos campos enfrentados, sino que se asienta, más sistemáticamente que en Balún Canán, en las propias conciencias de indios y ladinos. La "corriente de conciencia" indígena, centrada en la ilol o sacerdotisa Catalina, no se inspira ya en la retórica de los textos mayas petrificados por su transcripción y traducción; como en Los hombres verdaderos de Castro, adopta una flexibilidad que denota a la vez la familiaridad con las escrituras de vanguardia y una aproximación intelectual más limitada al pensamiento indígena.

"Nos arrebataron la palabra...", reza la primera frase de Balún Canán, pronunciada por la nana tzeltal: las novelas de Rosario Castellanos, que sin duda intentan restituir esta palabra arrebatada, continúan de hecho, como los otros textos ladinos, desnaturalizándola. Pero Oficio de tinieblas, que se propone desmontar la sociedad regional en todas sus relaciones (sociales, étnicas, sexuales) y a partir de todas las perspectivas, no pudo prescindir de ella: la polifonía así lograda salva, sin duda, la legitimidad del resultado.

Con Benzulul ${ }^{46}$, pequeño libro de cuentos publicado, de hecho, tres años antes que Oficio de tinieblas (1962), Eraclio Zepeda revoluciona profundamente la escritura "indigenista" o "etnoficcional" del área maya. Su punto de partida, que determinará las características principales de su mundo narrativo, es una nueva interpretación de la figura social del "indio". Recapitulemos los diferentes enfoques socio-culturales de esta figura, que subyacen en los textos discutidos hasta ahora. El Indio con mayúscula de Mediz Bolio resulta un antepasado mítico y mistificado de ciertos intelectuales yucatecos que se consideran herederos de una identidad "maya". Los mayas de Abreu Gómez tienden a encarnar un proletariado sui generis, protagonista de una revolución étnicosocial. En Asturias, los indios guatemaltecos mitificados, despro-

War" of 1869", en MURDO J. MACLEOD y ROBERT WASSERSTROM, Spaniards and Indians in Southeastern Mesoamerica, Lincoln, London, 1983.

${ }^{45}$ VICENTE PINEDA, Historia de las sublevaciones indígenas en el estado de Chiapas, Gobierno del Estado, Chiapas, 1888.

46 ERACLIO ZEPEDA, Benzulul, Universidad Veracruzana, Xalapa, 1959. 
vistos de rasgos étnicos específicos, configuran el núcleo de una identidad nacional (ladina) por crear. Para los antropólogos Pozas y Castro, los grupos étnicos tzotzil y tzeltal (colectividades y conjuntos de individuos) son el "otro" que importa conocer y defender en cuanto a sus valores "étnicos". Rosario Castellanos, apoyándose en los conocimientos antropológicos ya existentes, se centra en las complejas relaciones que se tejen entre los diferentes sectores indígenas y los diversos grupos ladinos en el seno de la sociedad regional chiapaneca; en sus textos, ni los "indios" ni los "ladinos" existen fuera de sus relaciones recíprocas.

Los personajes de Zepeda ya no son "indios" sino campesinos; una categoría de campesinos mexicanos que conserva o actualiza una serie de comportamientos de origen "indígena". La decisión de convertir a los "indios" en campesinos, fundada en una observación confirmada recientemente por el análisis sociológi$\mathrm{co}^{47}$, provoca, en el campo de la estética literaria, unas consecuencias importantes. Ver a los "indios"' bajo su aspecto de campesinos significa negar su exotismo, contribuye a disminuir la distancia entre el autor (ladino) y sus personajes. En tanto que campesinos, en efecto, los "indios" hablan español (aunque conserven, para determinadas circunstancias, su idioma); su universo intelectual, rural y arcaico pero no "indígena", deja de ser radicalmente "otro" con respecto a un universo intelectual provinciano. Desde luego, la simple decisión de convertir a los "indios" en campesinos no resuelve, de por sí, los problemas estéticos de la ex-etnoficción o "agro-ficción". Todo depende ahora de la capacidad del autor para inventar un lenguaje artístico que traduzca convincentemente las implicaciones de la nueva estrategia. Zepeda elabora el lenguaje de los indios-campesinos no a partir de textos escritos antiguos (Asturias, Rosario Castellanos), ni en base a la sintaxis y las imágenes de un idioma indígena actual (Castro), sino tratando de potenciar artísticamente, como Juan Rulfo, un sociolecto hispánico rural. La mayoría de los cuentos de Benzulul alternan el discurso de un narrador "anónimo" con el discurso, directo o interior, de un protagonista; es altamente significativo que estos dos discursos se distingan prácticamente sólo por el cambio del pronombre: él/yo. El narrador, por lo tanto, se halla mimetizado en un universo discursivo que lleva todos los signos de lo oral y lo "popular'. Desaparece así la oposición de registros (discurso "indígena"/discurso ladino) que caracterizaba las novelas de Rosario Castellanos; disminuye la distancia entre un discurso indígena

${ }^{47}$ Christian DeverRe, op. cit. 
de ficción y el probable horizonte discursivo del lector (Castro). Si el lenguaje narrativo es un sociolecto rural artísticamente elaborado, la cosmovisión expresada, otra vez como en Rulfo, es la de un campesinado sin duda arcaico, pero ya no protegido por la organización comunitaria de las subsociedades indígenas. A pesar de que una oposición campesinos pobres/representantes del sector hegemónico (abigeos, funcionarios, fuerzas represivas) diseña el telón de fondo social de los cuentos de Zepeda, cada personaje se encuentra (como en Rulfo), solitario y aislado frente a una violencia omnipresente y arbitraria. El pensamiento antiguo, actualización de núcleos de origen indígena, carece de eficacia en este contexto "desindigenizado", aunque resulte, a los ojos de los protagonistas y sus dobles, los narradores, capaz de explicar - pero no de transformar- el mundo. El cuento "Benzulul", por ejemplo, no niega que el poder del abigeo Encarnación Salvatierra radique en su patronímico español (variante de la difundida creencia mayance según la cual los ladinos son dueños de un nahual o espíritu protector más poderoso que el de los indios); pero al sustituir por el patronímico fuerte del abigeo su apellido maya, Benzulul incurre en la venganza asesina del ladino. En "Patrocinio Tipá", la circunstancia de que una urraca se llevara el ombligo del personaje recién nacido -impidiendo así que sus padres, según los códigos vigentes, lo enterraran-, explica la serie de desastres que sufrirán él y su familia, pero este saber no permitirá evitarlos. Un esquema análogo rige la mayoría de los cuentos. Los códigos indígenas todavía respetados por estos campesinos resultan, por lo tanto, un obstáculo para una toma de conciencia política. Los "indios" han sido abandonados, definitivamente, por sus "dioses". En todos sus niveles, Benzulul señala el fin de una época y de una práctica literaria; su "mensaje" podría sintetizarse así:

Los "indios" dejaron de ser indios, y su saber tradicional no ofrece ya perspectivas para mejorar su situación. La Colonia, con su dicotomía aparentemente étnica, ha dejado de existir, y con ella, la hipótesis de cualquier restauración del orden antiguo. El mesianismo intelectual basado en la esperanza de un resurgimiento indio deja de ser vigente en medio de un rápido y profundo proceso de transformación capitalista, acompañado por la crisis de la solidaridad ancestral de los "indios". La defensa de los valores culturales de los indios no hace sino disimular su ineficacia actual. Considerar estos valores, por otra parte, como vehículo de una hipotética identidad nacional o regional, no pasa de ser una mistificación ideológica. No quedan sino opresores y oprimidos, pero éstos no han tomado conciencia todavía de su situación. El inte- 
lectual ladino, dejando de atribuirse el papel de guía espiritual de los "indios", debe buscarse una legitimación más adecuada.

Este "mensaje", extraído de los diferentes niveles de significación del texto, parece profundamente pesimista, puramente destructivo. Subsiste, sin embargo, la realidad del texto artístico en tanto que tal. Por encima de los despojos del indigenismo ideológico o social, y de la etnoficción, el discurso narrativo de Zepeda construye su propio signo artístico, irreductible a las ideologías preexistentes e irrecuperable, a raíz de su carácter desmitificador, por los opresores. El compromiso con la literatura, cuando ésta logra elevar "a la más alta categoría artística el difícil lenguaje del pueblo", como afirmaba José María Arguedas ${ }^{48}$ a propósito de Rulfo, resulta el mejor compromiso con los oprimidos que un escritor puede realizar.

MARTIN LIENHARD

Freie Universität Berlin

48 "Reflexiones peruanas sobre un narrador mexicano", El Comercio, Lima, 8 de mayo de 1960 , p. 3. 